\title{
Study of the areas and thicknesses of mesiobucal root canals prepared by three endodontic techniques
}

\author{
Estudo das áreas e espessuras de canais \\ radiculares mésio-vestibulares preparados por \\ três técnicas endodônticas
}

\section{Isa Geralda Teixeira Constante(a) Harry Davidowicz ${ }^{(b)}$ \\ Fernando Branco Barletta ${ }^{(c)}$ Abilio Albuquerque Maranhão de Moura ${ }^{(d)}$}

(a) MSc in Endodontics; ${ }^{(b)}$ Full Professor; ${ }^{(d)}$ Full Professor and Chairman - Department of Endodontics, Paulista University, São Paulo.

(c) Professor, Graduate Program in Endodontics, Lutheran University of Brazil, Canoas.

\section{Corresponding author:}

Abilio Albuquerque Maranhão de Moura Rua Barão do Triunfo, 1650, ap. 22, Campo Belo, São Paulo - SP - Brazil CEP: 04602-006

E-mail:aammoura@usp.br

Received for publication on Mar 27, 2006 Sent for alterations on Sep 13, 2006 Accepted for publication on Dec 07, 2006

\begin{abstract}
The purpose of this study was to compare, in vitro, by means of computerized analysis of digital radiographic images, the anatomic alterations produced in the mandibular molar tooth dentinal walls of mesiobucal canals with severe curvature by three different endodontic techniques: Progressive Preparation, Staged and Serial Preparation. A selection was made of 45 extracted, human, mandibular molars, with root curvatures greater than $25^{\circ}$. They were divided into three groups for every technique studied, which were then sub-divided into three sub-groups in accordance with the position of the curvature along the root: cervical, median or apical. After access surgery and tooth length determination, the canals were filled with $100 \%$ Barium Sulphate radiological contrast and the teeth were then radiographed with a direct digital radiography system, using a special apparatus capable of keeping the samples in the same spatial position during the different radiographic takes. After the above-mentioned endodontic techniques had been performed, the teeth were again filled with Barium sulphate and were also radiographed under the same previously mentioned conditions. The pre- and post-operative digital images were then analyzed in two computerized programs, AutoCAD 2004 and CorelDraw 10, to assess, respectively, the areas and the horizontal alterations which occurred in the internal and external walls of the root canals. The results indicated that although no significant differences among the techniques were shown in the statistical analysis, in a descriptive analysis the Progressive Preparation technique was shown to be more regular, uniform and effective.
\end{abstract}

Descriptors: Root canal therapy; Root canal, anatomy \& histology; Digital radiography; Contrast media.

Resumo: Objetivou-se comparar, in vitro, através de análise computadorizada de imagens radiográficas digitais, as alterações anatômicas promovidas nas paredes dentinárias de canais mésio-vestibulares com curvatura severa de molares inferiores por três técnicas endodônticas diferentes: Preparo Progressivo, Escalonada e Seriada. Foram selecionados 45 molares inferiores humanos extraídos, com curvaturas radiculares superiores a $25^{\circ}$, que foram divididos em três grupos para cada técnica estudada e subdivididos em três subgrupos de acordo com a posição da curvatura ao longo da raiz: cervical, mediana ou apical. Após cirurgia de acesso e odontometria, os canais foram preenchidos com contraste radiológico de sulfato de Bário a $100 \%$ e os dentes então foram radiografados por um sistema de radiografia digital direta, utilizando-se um aparato capaz de manter as amostras na mesma posição espacial nas diferentes tomadas radiográficas. Após a realização das técnicas endodônticas supracitadas, os dentes foram novamente preenchidos com o sulfato de Bário e radiografados nas mesmas condições anteriores. As imagens digitais pré e pós-operatórias foram então analisadas em dois programas computadorizados, o AutoCAD 2004 e o CorelDraw 10, para verificar, respectivamente, as áreas e as alterações horizontais ocorridas nas paredes internas e externas dos canais radiculares. Apesar de não ter havido diferenças significantes entre as técnicas na análise estatística, em uma análise descritiva a técnica do Preparo Progressivo mostrou-se mais regular, uniforme e eficaz.

Descritores: Tratamento do canal radicular; Canal radicular, anatomia \& histologia; Radiografia digital; Meios de contraste. 


\section{Introduction}

The presence of alterations in the internal anatomy of the canal, such as different angulations of curvatures, isthmus, and apical deltas, among others, make the maintenance of the original anatomy of the canal a difficult objective to attain. Several studies ${ }^{5,10,16,18}$ have investigated the ability of endodontic techniques to maintain the root canal in its initial position, quantifying the occurrence of apical deviations, zips, loss of working length and other undesirable alterations in the final shape of the preparation.

A great deal of study has been done about the correlation between these deformations and the instruments used during root canal preparation. Since Endodontics began, the use of manual files has caused concern both to researchers and clinicians, who endeavored to diminish the risks of undesirable occurrences caused by manual instrumentation. The use of Nickel-Titanium files led to a lower possibility of these deviations occurring. ${ }^{7,13,19}$

The Serial Technique was the first technique introduced for the treatment of either straight or curved root canals. ${ }^{8}$ The Staged Technique appeared to attempt to avoid the undesirable alterations of the previous technique, proposing a withdrawal in the working length for instruments with a higher caliber. It was indicated for the treatment of canals with a curvature. ${ }^{20}$

The "Progressive Preparation Technique", based on the crown-apex principle, recommended a differentiated use of manual files, combining the use of K, Flex and NiTi type files depending on the root curvature. Thus, it offered a safe alternative for the treatment of canals with accentuated curvature. ${ }^{11}$

The aim of this study was to compare the Progressive Preparation, Staged and Serial techniques as regards greater efficacy and less risk of undesirable alterations in the original anatomy of root canals with severe curvatures, located in different positions along the root, by means of computerized analyses of digital radiographic images.

\section{Material and Methods}

A selection was made of 45 teeth according to the Berbert $\&$ Nishiyama method ${ }^{1}$ for the root curvature position, and according to the Schneider method ${ }^{15}$ for the degree of curvature. The selected teeth were divided into three groups: one for the Serial Technique, one for the Staged Technique and one for the Progressive Preparation Technique. Each group was sub-divided into three sub-groups, depending on the curvature: Sub-group A - cervical curvature, subgroup B - median curvature and sub-group C - apical curvature. All the samples had a root curvature angulation greater than 25 degrees.

The mesiobucal canals of each sample were filled with a radiological contrast of $100 \%$ Barium sulphate and radiographed by a direct digital radiographic system with the aid of an apparatus that guaranteed that the radiographs before and after instrumentation would be in the same spatial position.

The Serial Technique was performed with instruments worked along the working length, up to instrument number $30 .{ }^{8}$

The Staged Technique was performed sequentially up to instrument \#25 (Dentsply Maillefer, Ballaigues, Switzerland), which was denominated the "memory instrument". The staged preparation was performed next with a $1 \mathrm{~mm}$ reduction of the working length for each increase in instrument caliber, at all times reviewing the total working length with the memory instrument. ${ }^{20}$

The Progressive Preparation Technique was performed by initially preparing the entry orifice of the canals with "Moura Manual Wideners", these instruments being confected by cutting $31 \mathrm{~mm}$ type $\mathrm{K} \# 80, \# 70$ and \#60 files (Dentsply Maillefer, Ballaigues, Switzerland) with a Carborundum disk to a length of $20 \mathrm{~mm}$ and then wearing their tips, used with half-turn maneuvers in a clockwise direction. After the length determination procedure, the canal was prepared up to at least file \#25, which was denominated the "memory instrument". This instrument was then put into the canal up to the working length passively, without acting actively against the tooth canal walls. The crown-apex preparation then began with a $\mathrm{K}$ type instrument, with a diameter 4 times greater than that of the memory instrument, working in filing movements without apical pressure on the most cervical and middle regions of the canal. 
The next instruments were of successively smaller calibers and reached an increasing apical depth of the root canal, at all times interspersed with the memory instrument, up to the working length, in this greater to smaller sequence, until the memory instrument number was attained. The memory instrument was then replaced by a NiTi instrument (Dentsply Maillefer, Ballaigues, Switzerland) of the same number, which was now worked actively in the apical region, followed by another NiTi instrument of the immediately higher diameter, number 30 , in the working length to perform apical preparation. The apical preparations were performed with $\mathrm{NiTi}$ instruments, as all the teeth had curvatures greater than 25 degrees, i.e. severe curvatures. ${ }^{11}$

The root canal preparations of all the techniques were performed with $1 \% \mathrm{NaOCl}$.

New, final radiographs were taken after the endodontic techniques had been performed, which were superimposed on the initial ones in order to analyze widening.

Analyses were made using the AutoCAD 2004 program (Autodesc, Inc., USA) to determine the partial and total areas of images before and after the preparations. The program imported the images and, by means of multiple points (Polyline tool), it outlined the image of the canal thus making an irregular polygon. The program offered the areas of the polygons relative to the cervical, median and apical thirds. The sum of the partial areas resulted in the value of the total area (Figures 1 and 2). Widening was assessed by the difference between the final and initial areas.

In the CorelDraw 10 program (MicroSafe, RJ, Brazil) the canal thicknesses before and after the preparations were assessed by analyzing the horizontal alterations observed in the internal and external walls of the mesiobuccal canal of each sample.

Straight lines were traced at five equidistant points along the canal, starting from a reference guide line up to the external wall of the canal. They were denominated straight lines $\overline{\mathrm{AB}}$ (Figure 3). New straight lines were traced in relation to the internal wall, and they were denominated straight lines $\overline{\mathrm{AC}}$ (Figure 4).

The difference between straight lines $\overline{\mathrm{AC}}$ and straight lines $\overline{\mathrm{AB}}$ revealed the thickness of the canal $(\overline{\mathrm{BC}})$ (Figure 5).

The thicknesses of the canals before and after preparations were then determined and superimposed. Superimposition of an image of the canal thickness before preparation on an image of the
Figure 1 - Analysis of pre-operative areas.

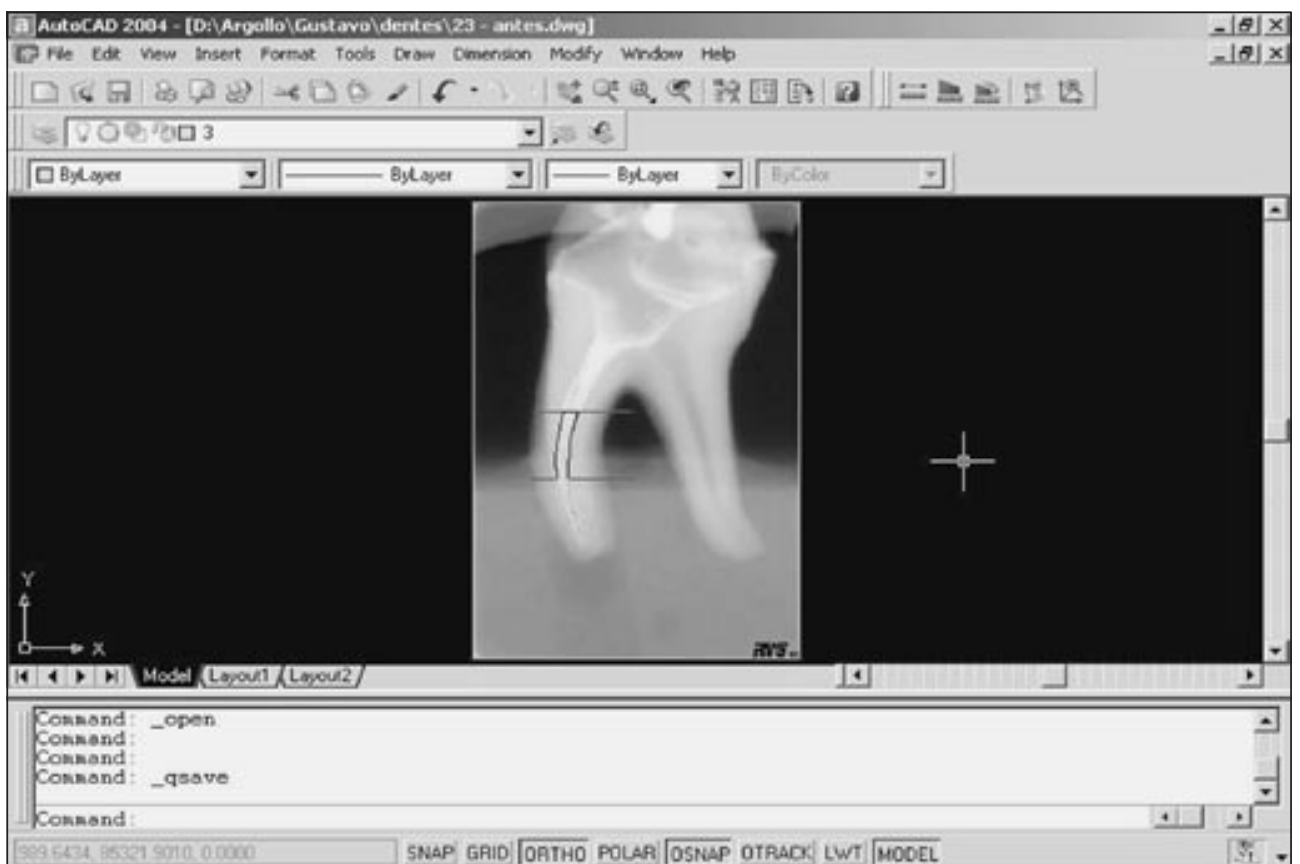




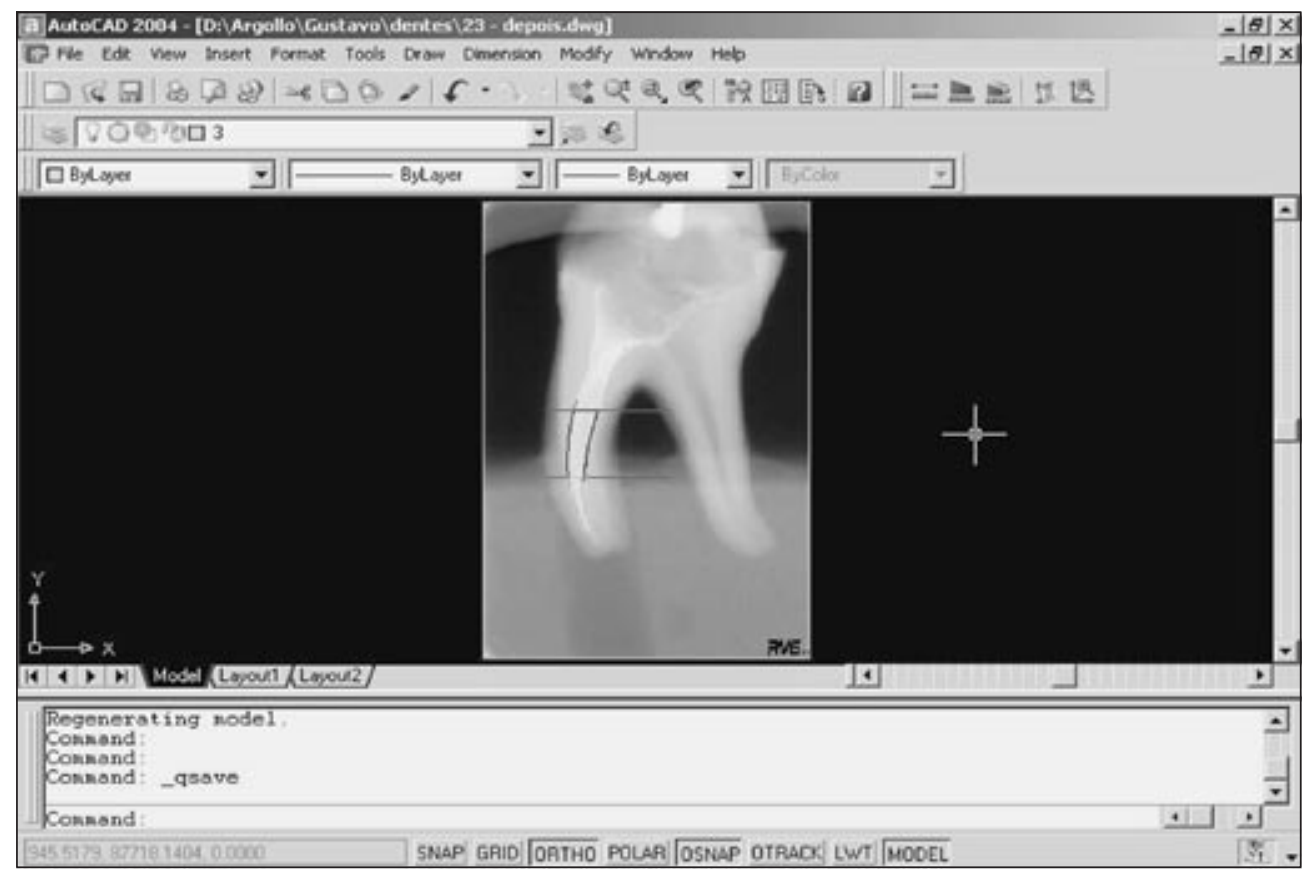

Figure 2 - Analysis of post-operative areas.

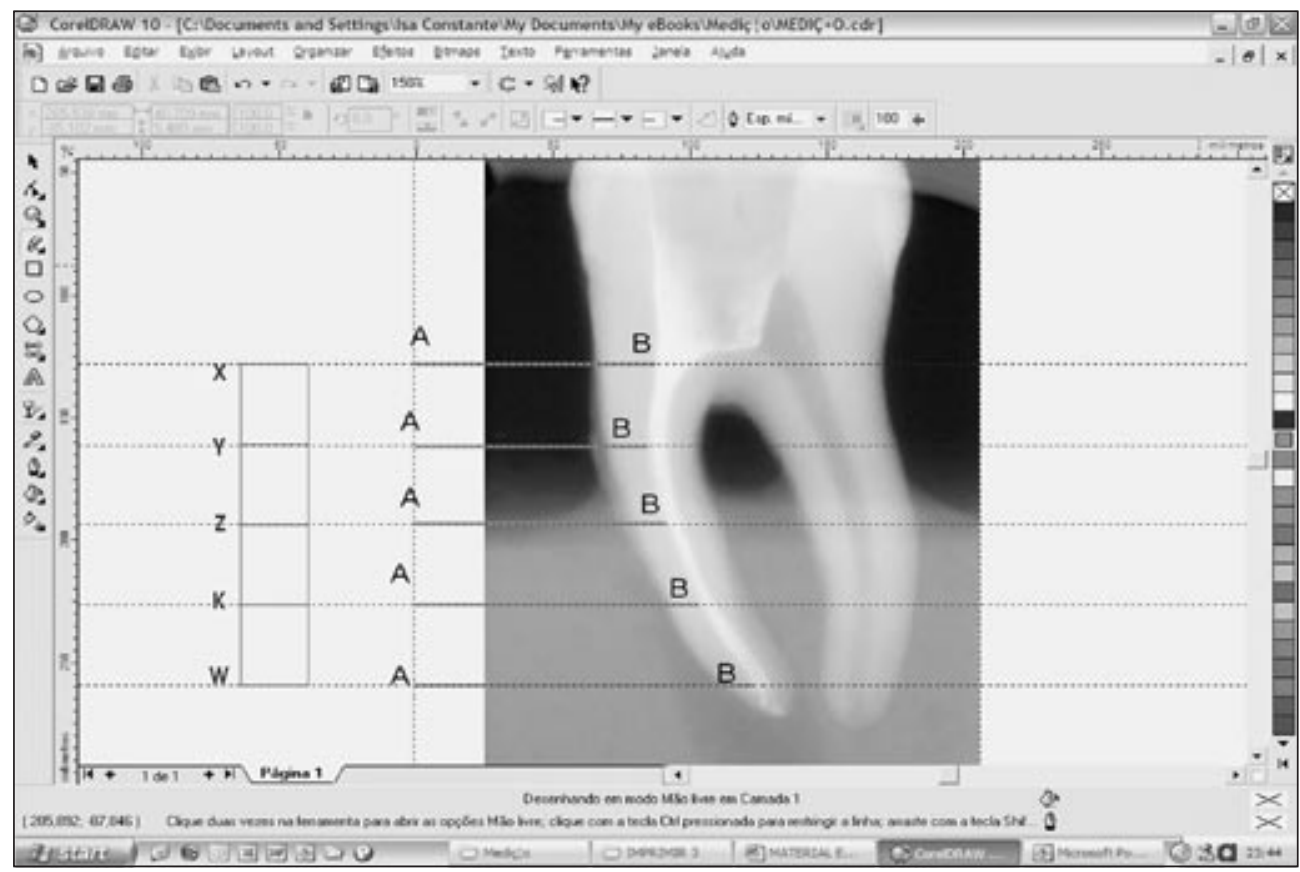

Figure 3 - Straight lines $\overline{\mathrm{AB}}$.

canal thickness after preparation is able to show the canal wall at whose expense the widening occurred.

In order to do image superimposition, some of the tools available in CorelDraw10 were applied: "Effects" and "invert", to transform light into dark and vice-versa; "Interactive Transparency", to enable visualization of the two superimposed images; and "Brightness-contrast-intensity", for small adjustments. By doing so, a better visualization was obtained of the two superimposed thicknesses (the pre-operative images were inverted and seen in 
Figure 4 - Straight lines $\overline{\mathrm{AC}}$.

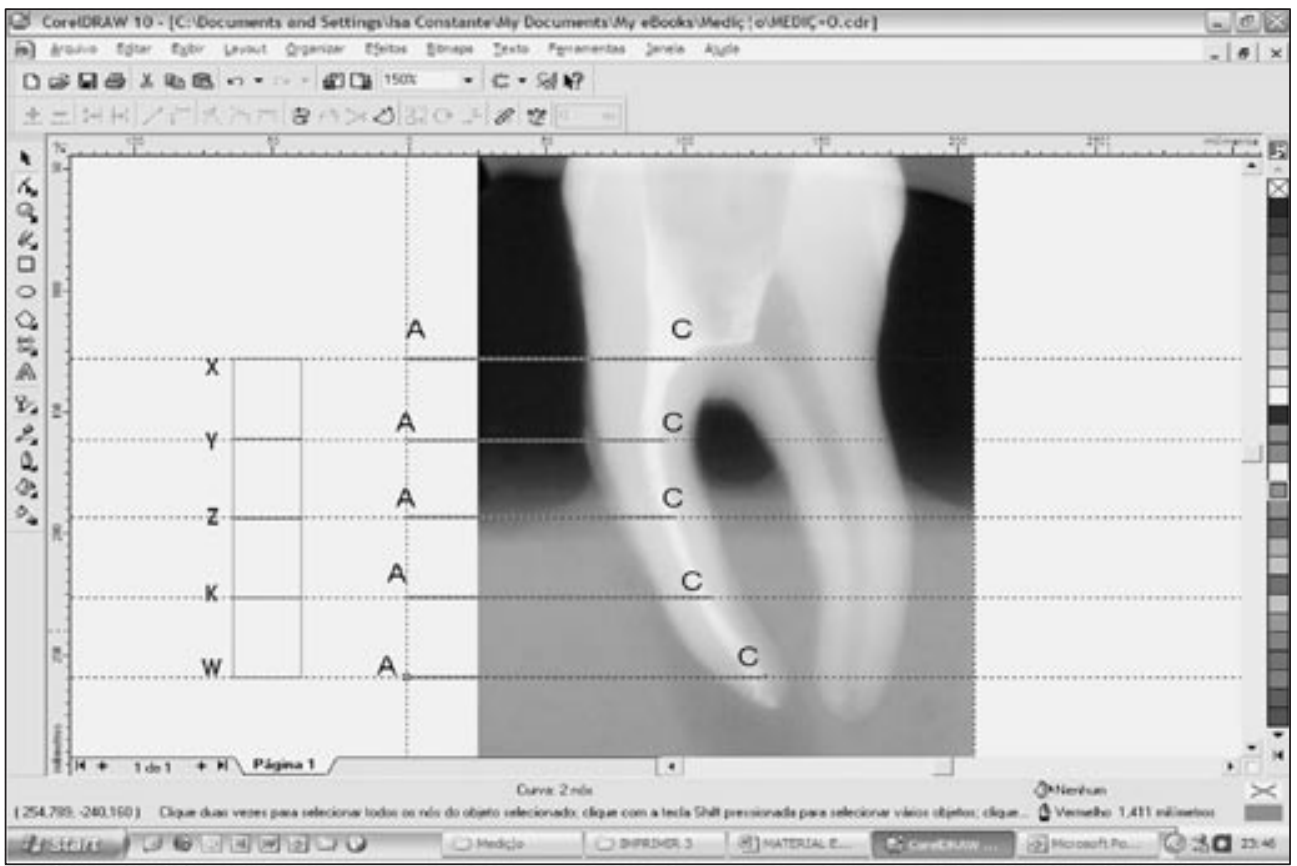

Figure 5 - Initial canal thickness $-\overline{\mathrm{BC}}$.

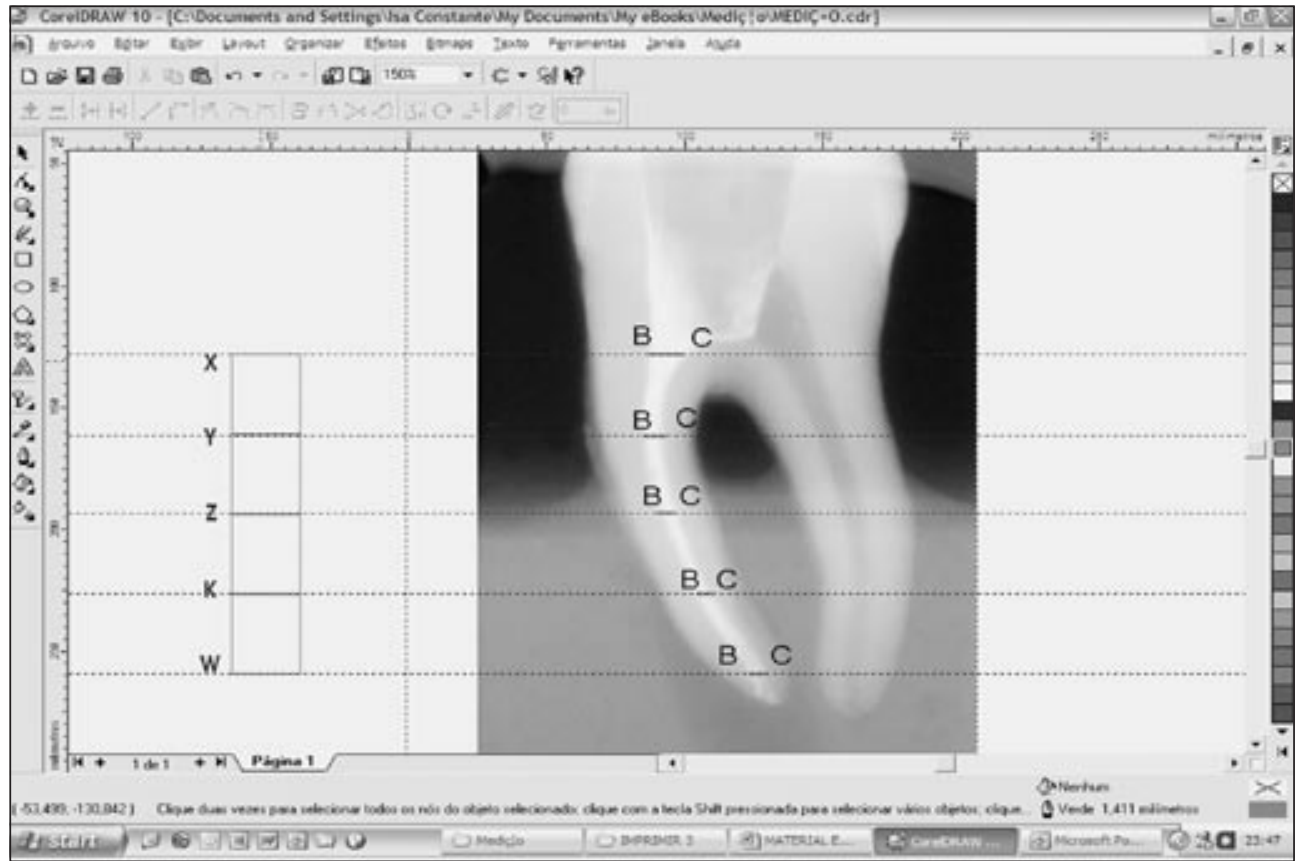

black, and the post-operative ones became semitransparent and seen in white) in the different techniques studied (Figure 6).

In this case, widening was assessed by the difference between the final and initial thicknesses (straight lines $\overline{\mathrm{BC}}$ ).

\section{Results}

A descriptive analysis of the areas showed that in all the locations considered, the Progressive Preparation Technique presented greater widening when compared with the other techniques. In greater detail, considering the total tooth area, in spite of the 


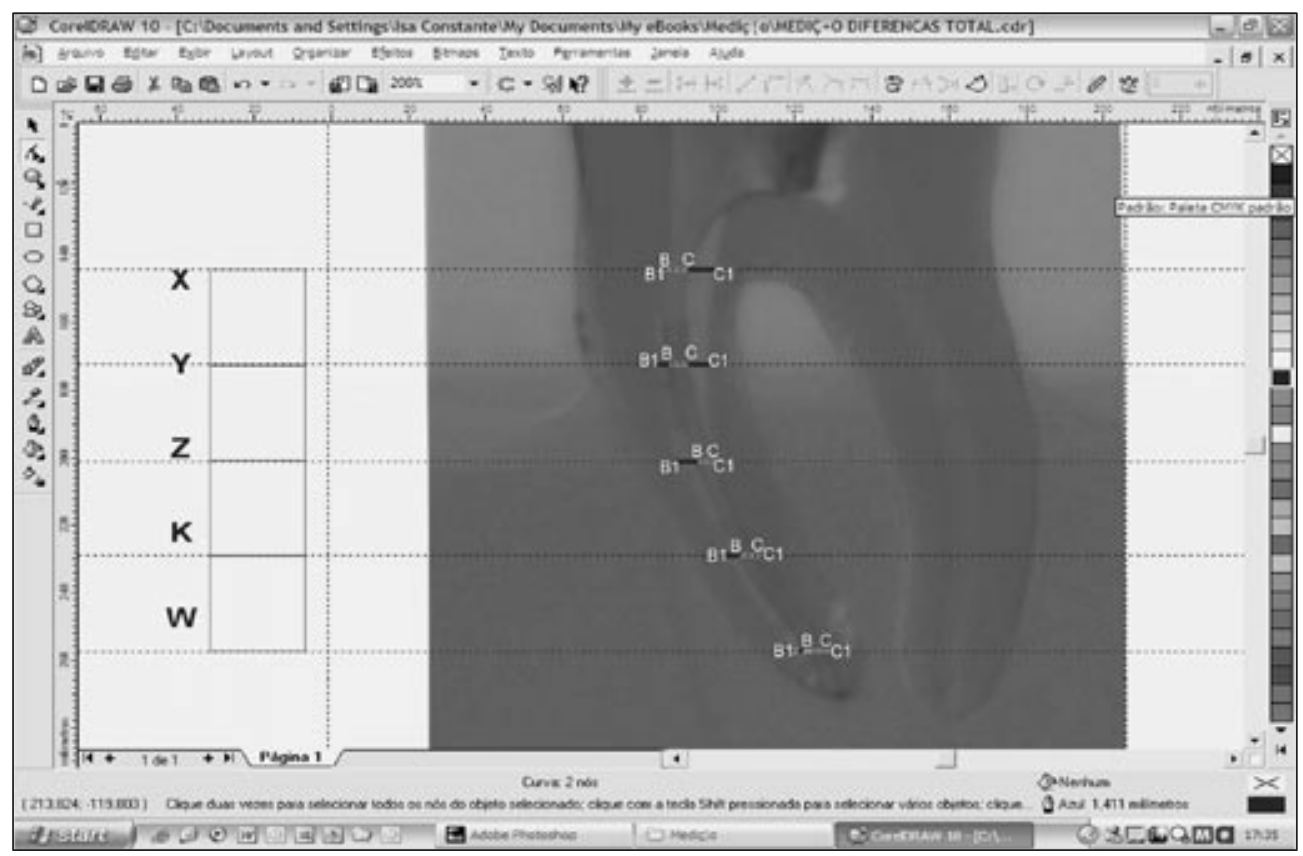

Figure 6 - Initial thickness superimposed on the final thickness.

Table 1 - Difference between initial and final areas in $\mathrm{mm}^{2}$, according to location and technique.

\begin{tabular}{|c|c|c|c|c|c|c|c|}
\hline \multirow{2}{*}{ Location } & \multirow{2}{*}{ Technique } & \multicolumn{6}{|c|}{ Descriptive Measurements } \\
\hline & & No. of Observations & Minimum & Mean & Median & Standard Deviation & Maximum \\
\hline \multirow{3}{*}{ Total } & Serial & 15 & 0.510 & 1.278 & 1.210 & 0.580 & 2.670 \\
\hline & Staged & 15 & 0.100 & 1.223 & 1.330 & 0.661 & 2.680 \\
\hline & Progressive & 15 & 0.420 & 1.349 & 1.510 & 0.466 & 2.100 \\
\hline \multirow{3}{*}{ Cervical } & Serial & 15 & -0.120 & 0.556 & 0.390 & 0.297 & 1.120 \\
\hline & Staged & 15 & 0.100 & 0.419 & 0.530 & 0.257 & 0.790 \\
\hline & Progressive & 15 & 0.030 & 0.530 & 0.650 & 0.255 & 0.910 \\
\hline \multirow{3}{*}{ Median } & Serial & 15 & 0.190 & 0.466 & 0.440 & 0.234 & 1.080 \\
\hline & Staged & 15 & 0.030 & 0.509 & 0.440 & 0.322 & 1.350 \\
\hline & Progressive & 15 & 0.080 & 0.497 & 0.520 & 1.888 & 0.860 \\
\hline \multirow{3}{*}{ Apical } & Serial & 15 & 0.000 & 0.265 & 0.240 & 0.193 & 0.710 \\
\hline & Staged & 15 & 0.000 & 0.299 & 0.310 & 0.227 & 0.700 \\
\hline & Progressive & 15 & 0.005 & 0.327 & 0.330 & 0.151 & 0.630 \\
\hline
\end{tabular}

Progressive Preparation presenting 0.420 for the minimum value and 2.100 for the maximum value, the mean and median values were higher and the standard deviation was the lowest obtained, indicating a greater precision of the results found when compared with the results of the other techniques (Table 1).

Graph 1 demonstrates that the results were closer to each other for the Progressive Preparation tech- nique, that is to say, the variation among the results obtained was smaller (this same result is confirmed by the standard deviation, which was the lowest for this technique). The greatest widening was found through the median (line traced inside the rectangles) which was shown to be in a superior position to the others.

With regard to the thicknesses, the Serial Technique presented the best results at point $\mathrm{X}$, whereas 
the Progressive Preparation technique presented the best results at points $\mathrm{Y}, \mathrm{Z}$ and $\mathrm{K}$, which demonstrates a greater regularity of the latter technique along the canal. At point W, the Staged technique presented the greatest widening (Table 2).

Negative values in the final thicknesses indicated the occurrence of deformations (negative deviations) in the prepared canals. These were observed in six samples in the Serial technique.

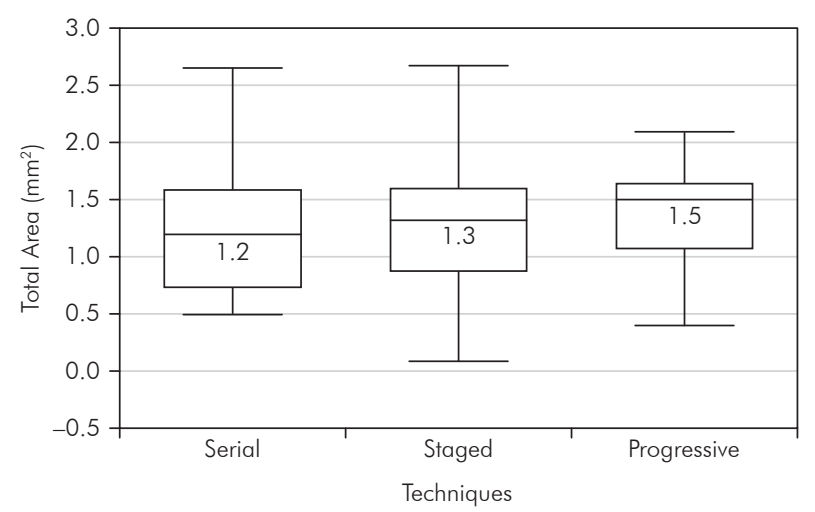

Graph 1 - Comparison between the standard deviations and medians between the techniques in accordance with the initial and final differences.
However, statistical analysis of the area and thickness data, performed by means of the Kruskal-Wallis test, did not lead to statistically significant differences among the techniques, considering the curvatures ( $\mathrm{p}$-value $>0.05$ in the three groups) (Table 3$)$.

\section{Discussion}

With regard to the descriptive analysis of the difference between final and initial areas (Table 1 and Graph 1), the Progressive Preparation technique showed closer results, thus indicating a more regular preparation. As regards the total area, it presented a greater value for the mean and the median, which indicated better performance. As regards the partial areas, the Serial and Staged techniques presented a greater maximum value in the cervical and median regions, respectively. However, the highest standard deviations of these techniques in the regions referred to showed greater irregularity in the preparations.

Widening done in a uniform manner is in agreement with the concepts of cleaning and modeling of Schilder ${ }^{14}$, who considered that, in chemical-surgical preparation, the final object of the action of wid-

Table 2 - Widening (in $\mathrm{mm}$ ) of the canals of 45 teeth, measured after the application of three techniques, in different locations.

\begin{tabular}{|c|c|c|c|c|c|c|c|}
\hline \multirow{2}{*}{ Location } & \multirow{2}{*}{ Technique } & \multicolumn{6}{|c|}{ Descriptive Measurements } \\
\hline & & No. of Observations & Minimum & Mean & Median & Standard Deviation & Maximum \\
\hline \multirow{3}{*}{$x$} & Serial & 15 & -3.520 & 4.200 & 4.122 & 3.555 & 11.800 \\
\hline & Staged & 15 & 0.803 & 3.696 & 3.307 & 2.246 & 7.880 \\
\hline & Progressive & 15 & 0.001 & 4.148 & 4.819 & 2.538 & 7.920 \\
\hline \multirow{3}{*}{ Y } & Serial & 15 & 0.341 & 3.446 & 2.790 & 2.181 & 7.472 \\
\hline & Staged & 15 & 0.010 & 3.607 & 3.570 & 2.199 & 8.330 \\
\hline & Progressive & 15 & 0.994 & 4.902 & 5.310 & 2.123 & 9.678 \\
\hline \multirow{3}{*}{ Z } & Serial & 15 & 0.640 & 3.148 & 3.010 & 2.255 & 7.126 \\
\hline & Staged & 15 & 1.040 & 3.968 & 4.110 & 1.930 & 8.600 \\
\hline & Progressive & 15 & 0.415 & 4.232 & 3.892 & 1.729 & 6.979 \\
\hline \multirow{3}{*}{ K } & Serial & 15 & -2.440 & 2.571 & 2.460 & 2.517 & 8.340 \\
\hline & Staged & 15 & 0.417 & 2.939 & 2.450 & 1.658 & 5.860 \\
\hline & Progressive & 15 & 0.339 & 3.953 & 3.953 & 1.607 & 5.511 \\
\hline \multirow{3}{*}{ W } & Serial & 15 & 0.020 & 1.293 & 0.574 & 1.524 & 5.070 \\
\hline & Staged & 15 & 0.110 & 1.859 & 1.090 & 1.667 & 5.320 \\
\hline & Progressive & 15 & 0.059 & 1.790 & 1.190 & 1.622 & 5.530 \\
\hline
\end{tabular}


Table 3 - Result of the Kruskal-Wallis Test for analyzing the areas.

\begin{tabular}{c|c|c}
\hline \multicolumn{3}{|c}{ Curvature } \\
\hline Apical & Median & Cervical \\
\hline 0.867 & 0.177 & 0.792 \\
\hline
\end{tabular}

ening the canal was to model it, in which the final shape respected the original one, but assumed a funneled and regular shape.

Although the final preparations for all the techniques would be standardized with a \#30 file, the Progressive Preparation technique presented a better performance in the region for all the groups of teeth, principally for the teeth with apical curvature. This may be explained by the removal of the cervical interferences before apical preparation, as recommended by the technique referred to. This enabled a better control of the instrument in the apical region and, consequently, a greater advantage to be taken of its kinematics.

These results corroborate those of Contreras et al. ${ }^{3}$ (2001), Goerig et al. ${ }^{6}$ (1982), Holland et al. ${ }^{9}$ (1991) and Nishiyama, Garcia ${ }^{12}$ (1993), who agreed that initial preparation of the cervical region facilitates the subsequent action of the instruments in the apical region.

Tan, Messer ${ }^{17}$ (2002), however, disagree. When comparing the manual apex-crown and crown-apex techniques with the LightSpeed techniques, they observed that there was no statistically significant difference between those techniques in relation to apical deviation and shape of the canal, which was also observed by Testa $^{18}$ (2003) when he compared manual and rotary crown-apex and apex-crown techniques.

As regards the thicknesses, the Progressive Preparation technique presented a better performance at three of the five levels studied, showing greater regularity of the preparation along the canal (Table 2).

Negative deviations occurred in six samples in the Serial technique. The fact that both the Staged and the Progressive Preparation techniques did not present negative deviations indicated that the use of instruments of different flexibilities for final preparation (stainless steel for the Staged technique and Nickel-Titanium for the Progressive Preparation) was not a factor that determined whether or not deviations occurred.
This is in agreement with the work of Testa ${ }^{18}$ (2003), Pereira et al. ${ }^{13}$ (2001) and Chan, Cheung ${ }^{2}$ (1996), who did not obtain statistically significant differences when they compared the results of preparations with stainless steel or Nickel-Titanium files.

It is, however, in disagreement with the work of Vanni et al. ${ }^{19}$ (2004) and Esposito, Cunningham $^{4}$ (1995), who studied the alterations that various endodontic techniques produced in the curved canals of extracted teeth, and concluded that those that used Nickel-Titanium files were more capable of maintaining the original anatomy; and of Souza et al. ${ }^{16}$ (2001), who compared the result of manual techniques with conventional files with that of automated Nickel-Titanium systems, and observed that the manual technique presented better results.

Although the descriptive analysis points towards a better performance of the Progressive Preparation technique in comparison with that of the other preparations, statistical analysis did not present significant statistical difference at the 5\% level of significance for decision making.

\section{Conclusions}

Based on an analysis of the results, it was concluded that:

1. The Progressive Preparation technique tended to be shown as more effective, precise and regular in a descriptive analysis that compared the Serial, Staged and Progressive Preparation techniques, as it presented more uniform preparations in all of the groups of teeth with root curvatures in different positions.

2. Deformations (negative deviations) occurred in $40 \%$ of the samples only in the Serial technique, and did not occur in the other two techniques. The use of instruments of different flexibilities in the Progressive Preparation and Staged techniques was not a preponderant factor for determining the occurrence of deviations.

3. Although there were no statistically significant differences, the descriptive analysis indicates that, clinically, the Progressive Preparation technique presented a better performance in relation to the other preparations. 


\section{References}

1. Berbert A, Nishiyama CK. Curvaturas radiculares: uma nova metodologia para a mensuração e localização. Rev Gaúcha Odont. 1994;42(6):356-8.

2. Chan AW, Cheung GS. A comparison of stainless steel and nickel-titanium K-files in curved root canals. Int Endod J. 1996;29(6):370-5.

3. Contreras MA, Zinman EH, Kaplan SK. Comparison of the first file that fits at the apex, before and after early flaring. J Endod. 2001;27(2):113-6.

4. Esposito PT, Cunningham CJ. A comparison of canal preparation with nickel-titanium and stainless steel instruments. J Endod. 1995;21(4):173-6.

5. Gambil JM, Alder M, Del Rio CE. Comparison of NickelTitanium and Stainless Steel hand-file instrumentation using computed tomography. J Endod. 1996;22(7):369-75.

6. Goerig AC, Michelich RJ, Schultz HH. Instrumentation of root canals in molar using the step-down technique. J Endod. 1982;8(12):550-4.

7. Heck AR, Garcia RB. Avaliação radiográfica do desvio apical do canal radicular após a instrumentação manual com limas Flexofile, Flex-R, Onyx-R e o sistema mecânico rotatório Profile. Rev Fac Odont Bauru. 1999;7(3/4):27-32.

8. Heuer MA. The biomechanics of endodontic therapy. Dent Clin North Am. 1963;13(1):341-59.

9. Holland R, Souza V, Otoboni Filho JA, Nery MJ, Bernabé PFE, Mello W. Técnicas mistas de preparo do canal radicular. Rev Paul Odont. 1991;13(4):17-23.

10. Iqbal MK, Firic S, Tulcan J, Karabucak B, Kim S. Comparison of apical transportation between Profile and Protaper Niti rotary instruments. Int Endod J. 2004;37(6):359-64.
11. Moura AAM, Moura Netto C, Carvalho CF. Técnica do preparo progressivo do canal radicular. ACDC em Ação. 2003;15:22.

12. Nishiyama CK, Garcia RB. Estudo comparativo entre as técnicas de instrumentação escalonada regressiva, oregon modificada, Sistema Canal Finder e Canal máster "U” na limpeza de canais radiculares. Rev Odontol Univ São Paulo. 1993;7(12):173-9.

13. Pereira AJA, Fidel RAS, Fidel SR, Santa Cecília M, Duarte MAH. Comportamento das limas manuais de aço inoxidável e de Níquel-Titânio em relação ao transporte apical. Rev Bras Odontol. 2001;58(4):266-9.

14. Schilder H. Cleaning and shaping the root canal. Dent Clin North Am. 1974;18(2):269-96.

15. Schneider SW. A comparison of canal preparations in straight and curved root canals. Oral Surg Oral Med Oral Pathol. 1971;32(2):271-5.

16. Souza V, Otoboni Filho JA, Holland R, Nery MJ, Bernabé PFE, Dezan Junior E. Avaliação de alguns aspectos relacionados ao preparo manual e automatizado do canal radicular. Rev Paul Odont. 2001;23(5):22-4.

17. Tan BT, Messer HH. The quality of apical canal preparation using hand and rotary instruments with specific criteria for enlargement based on initial apical file size. J Endod. 2002;28(9):658-64.

18. Testa FM. Influência das Técnicas de instrumentação no desvio apical de canais radiculares [Dissertação de Mestrado]. Bauru: Faculdade de Odontologia de Bauru da USP; 2003.

19. Vanni JR, Albuquerque DS, Reiss C, Barato Filho F, Limongi O, Della Bona A. Apical displacement produced by rotary nickel-titanium instruments and stainless steel files. Appl Oral Sci. 2004;12(1):51-5.

20. Weine FS. Endodontic therapy. Saint Louis: Mosby; 1972. 